\title{
PENJADWALAN MATAKULIAH MENGGUNAKAN PEWARNAAN TITIK PADA GRAF
}

\author{
ZALFA AHMAD SYAUQI, MAHDHIVAN SYAFWAN \\ Jurusan Matematika, \\ Fakultas Matematika dan Ilmu Pengetahuan Alam, Universitas Andalas, \\ Kampus UNAND Limau Manis Padang, Indonesia, \\ email : zalfaahmad@gmail.com
}

\begin{abstract}
Abstrak. Permasalahan penjadwalan matakuliah di universitas adalah perencanaan pengalokasian sejumlah mata kuliah ke dalam sebuah kumpulan waktu dan ruang selama tidak melanggar constraints, yaitu syarat atau ketentuan penjadwalan. Pewarnaan titik pada graf merupakan salah satu cara yang dapat menyelesaikan permasalahan penjadwalan, dengan membentuk algoritma serta menetapkan constraints dan asumsi, penjadwalan matakuliah dapat dilakukan pada perkuliahan Jurusan Matematika Fakultas Matematika dan Ilmu Pengetahuan Alam Universitas Andalas.
\end{abstract}

Kata Kunci: Penjadwalan, pewarnaan titik pada graf, algoritma, kendala

\section{Pendahuluan}

Penjadwalan kelas matakuliah adalah suatu sistem penempatan waktu dan ruang dalam proses kegiatan belajar mengajar. Dalam hal ini, penjadwalan erat kaitannya dengan kapasitas dan keterbatasan ruang, waktu yang dibutuhkan, ketersedian dosen, serta banyaknya mata kuliah yang akan dijadwalkan. Penjadwalan mata kuliah di universitas dikenal dengan istilah University Course Timetabling Problem (UCTP) [2].

University Course Timetabling Problem (UCTP) adalah perencanaan pengalokasian sejumlah mata kuliah ke dalam sebuah kumpulan waktu dan ruang selama tidak melanggar syarat atau ketentuan penjadwalan. Dalam penjadwalan, terdapat istilah constraints yang berariti syarat atau ketentuan. Fungsi dari constraints dalam masalah penjadwalan adalah sebagai aturan sehingga jadwal yang dibentuk tidak terjadi masalah jika diterapkan [2].

Graph coloring merupakan metode sederhana dalam penjadwalan, yaitu dengan menerapkan konsep graph pada permasalahan penjadwalan. Dalam hal ini constraints didefinisikan sebagai edge dan matakuliah didefenisikan sebagai vertex sehingga akan dibentuk suatu graph. Pada graph coloring dapat dihasilkan lebih dari satu solusi selama solusi tersebut memenuhi constraints [2].

Konsep graph coloring yang sederhana ini dapat diterapkan dalam University Course Timetabling Problem (UCTP) dengan berbagai constraints yang dapat dipenuhi. Oleh karena itu, penulis tertarik dalam mengkaji penjadwalan mata kuliah dengan pewarnaan titik pada graf (vertex graph coloring). 


\section{Pewarnaan Titik Pada Graf}

Suatu graf $G$ didefinisikan sebagai pasangan himpunan $(V(G), E(G))$, dengan $V(G)$ adalah himpunan titik tak kosong dan $E(G)$ adalah himpunan sisi yang menghubungkan titik-titik pada $G$. Derajat (degree) dari sebuah titik $v$ di $G$ adalah banyaknya sisi di $G$ yang terkait dengan $v$, dinotasikan dengan $d(v)$. Jika untuk setiap $v \in V(G)$ berlaku $d(v)=r$, maka graf $G$ disebut graf $\boldsymbol{r}$-reguler. Secara khusus, graf 3 -reguler disebut graf kubik. Himpunan titik dari $G$ dengan derajat $\mu$ dinotasikan dengan $V_{\mu}$. Jika terdapat sisi $e=u v$ dengan $u, v \in V(G)$, maka titik $u$ disebut bertetangga (adjacent) dengan titik $v$, dan demikian sebaliknya. Dalam hal ini, sisi $e$ dikatakan terkait (incident) dengan titik $u$ dan $v$. Sebaliknya, titik $u$ dan $v$ juga dikatakan terkait dengan sisi $e$. Misalkan $x \in V(G)$, lingkungan (neighbourhood) dari $x$ adalah himpunan sisi yang terkait dengan titik $x$, dinotasikan dengan $N(x)$.

Suatu graf dapat diwarnai dengan memperhatikan titik dan sisi dalam graf tersebut. Terdapat dua pewarnaan graf, pewarnaan titik (vertex coloring) dan pewarnaan sisi (edge coloring), pewarnaan titik adalah pewarnaan dua titik $v$ di $G$ dimana dua titik tersebut tidak berada dalam satu sisi. Bilangan kromatik pada suatu graf $G$ merupakan jumlah warna minimum yang dapat digunakan pada titiktitik suatu graf $G$ pada pewarnaan titik.

\section{Algoritma Program}

Algoritma program merupakan suatu langkah-langkah dasar sebuah program, sehingga dapat diterapkan ke berbagai software tertentu dengan bahasa program yang berbeda-beda. Adapun algoritma program yang digunakan yaitu algoritma penjabaran, algoritma pembandingan, algoritma prioritas dan algoritma penyusunan.

\subsection{Algoritma penjabaran}

Algoritma penjabaran digunakan untuk menjabarkan data awal sehingga dapat digunakan dalam penyusunan jadwal. Adapun langkah-langkahnya sebagai berikut:

(1) Hitung jumlah data matakuliah.

(2) Lakukan perulangan sebanyak jumlah data matakuliah.

(2.1) Cek jumlah SKS.

(2.2) Cek jumlah kelas.

(2.3) Jabarkan data matakuliah setiap 2 SKS dan kelas yang berbeda.

(3) Simpan data pada langkah 2 sebagai data baru.

\subsection{Algoritma prioritas}

Algoritma prioritas digunakan untuk mengatur nomor shift yang diambil sehingga nomor shift tersebut sama dengan salah satu dari nomor shift yang diprioritaskan. Adapun langkah-langkahnya sebagai berikut:

(1) Tetapkan nomor shift yang diprioritaskan. 
(2) Tetapkan nomor shift secara acak.

(3) Jika nomor shift yang dipilih secara acak bukan nomor shift dalam prioritas, maka ulangi langkah 2 .

(4) Simpan nomor shift yang telah dipilih.

\subsection{Algoritma pembandingan}

Algoritma pembandingan digunakan untuk membandingkaan suatu data terhadap kelompok data tertentu. Bila memenuhi constraints maka data tersebut ditambahkan ke dalam kelompok data. Adapun langkah-langkahnya sebagai berikut:

(1) Tentukan variabel (constraints) pada data yang akan dibandingkan.

(2) Hitung jumlah data yang telah dikelompokkan.

(3) Lakukan perulangan sebanyak jumlah data yang telah dikelompokan.

(4) Bandingkan data dengan setiap data dalam kelompok.

(5) Simpan hasil dari tiap perbandingan.

\subsection{Algoritma penyusunan jadwal}

Algoritma penyusunan jadwal digunakan untuk menyusun jadwal dengan data yang telah diproses pada Algoritma 3.1, diatur posisinya dengan Algoritma 3.2, dan dengan menggunakan Algoritma 3.3 sehingga setiap penyusunan sesuai constraints. Adapun langkah-langkahnya sebagai berikut:

(1) Tetapkan data matakuliah.

(2) Jabarkan data matakuliah dengan algoritma 3.1

(3) Hitung banyak data yang diperoleh dari langkah 2.

(4) Lakukan perulangan sebanyak data yang diperoleh.

(4.1) Tentukan nomor shift data dengan Algoritma 3.2

(4.2) Lakukan perbandingan data dengan Algorima 3.3 dengan variabel yang ditentukan berdasarkan constraints yang berlaku.

(4.3) Jika hasil dari setiap perbandingan terpenuhi, data kuliah tersebut disimpan pada nomor shift yang diperoleh pada langkah 4.1.

(5) Selama seluruh data belum tersusun, proses diulang kembali.

\section{Kendala dan Asumsi}

\subsection{Asumsi}

(1) Setiap kuliah wajib memiliki maksimum 3 kelas dan kuliah pilihan maksimum 2 kelas.

(2) Setiap kuliah dapat ditempatkan pada sebarang waktu, namun harus memenuhi hard constraints.

(3) Setiap dosen dapat memberikan perkuliahan pada waktu yang ditentukan

(4) Setiap mahasiswa harus memilih kelas sesuai dengan ketentuan yang ditentukan prodi. 
(5) Setiap kuliah wajib atau pilihan dengan 3 SKS akan dibagi menjadi 1 kuliah 2 SKS dan 1 kuliah minggu genap/ganjil dengan bobot 2 SKS.

(6) Ruangan setiap kuliah tidak diperhitungkan (kesedian ruangan untuk setiap jadwal dapat dipenuhi).

\subsection{Hard Constraints}

(1) Dalam satu minggu, seluruh kuliah terlaksana sesuai bobot SKS dan banyak kelasnya.

(2) Setiap kuliah terdiri dari 2 SKS, 1 kelas, dan maksimal 3 dosen.

(3) Dalam hari yang sama, tidak ada jadwal dengan matakuliah dan kelas yang sama.

(4) Dalam shift yang sama, jadwal kuliah dengan semester yang sama harus berbeda kelas, kecuali keduanya merupakan kuliah genap dan ganjil.

(5) Dalam shift yang sama, tidak ada jadwal dengan matakuliah yang sama, kecuali keduanya merupakan kuliah genap dan ganjil.

\subsection{Soft Constraints}

(1) Dalam shift yang sama, tidak ada jadwal dengan kelas yang sama dan selisih 2 semester.

(2) Dalam shift yang sama, tidak ada jadwal dengan dosen yang sama.

\section{Penyusunan Jadwal Kuliah}

Penyusunan jadwal kuliah menggunakan software Matlab dengan menerapkan vertex graph coloring dalam penyusunannya dan data yang telah dijabarkan sebagai data yang akan disusun. Jadwal kuliah ditetapkan berlangsung selama lima hari (Senin - Jumat) dalam seminggu dimana setiap hari terdiri dari lima slot waktu (shift). Sehingga terdapat 25 shift yang akan ditempati oleh 133 data kuliah. Untuk selanjutnya, setiap shift diberi nomor dari $1-25$ secara berurut. Dengan software Matlab, penyusunan dapat dilakukan dengan mengikuti algoritma 3.4 dengan membentuk suatu script, untuk penyusunan menggunakan script utama dengan judul Jadwal.m, dan beberapa script lainnya dengan judul Hasil.m, CH.m, CS.m, CD.m, CMK.m, dan CK.m.

\section{Hasil Jadwal}

Setelah penyusunan jadwal kuliah berhasil, didapat hasil sebagai jadwal kuliah yang memenuhi constraints dengan bilangan kromatik yang diperoleh sebesar 23. Dengan menetapkan constraints dan asumsi yang diperlukan, penerapan vertex graph coloring dalam masalah penjadwalan matakuliah dapat dilakukan. Hasil penjadwalan yang diperoleh dapat digunakan pada perkuliahan di Prodi S1 Jurusan Matematika Fakultas Matematika dan Ilmu Pengetahuan Alama Universitas Andalas. Hasil selengkapnya dapat dilihat dalam [4]. 


\section{Daftar Pustaka}

[1] Chartrand, G. dan P. Zhang. 2005. Introduction to Graph Theory. McGraw-Hill International Editions, Singapore.

[2] Mariana dan Hiryanto, L. 2005. Penjadwalan Matakuliah menggunakan Vertex Graph Coloring dan Simulated Annealing. Teknik Informatika Universitas Tarumanagara, Jakarta Barat.

[3] Anonymous. No year. Graph Algorithms Vertex Coloring. www.sci.brooklyn.cuny.edu/ amotz/GC-ALGORITHMS/PRESENTATIONS/ coloring.pdf

[4] Syauqi, Z. A, 2017, Penjadwalan Mata Kuliah dengan Menggunakan Pewarnaan Titik pada Graf, Skripsi S1, tidak diterbitkan, Jurusan Matematika, FMIPA Universitas Andalas 